Collection: 3rd International Elm Conference, Florence (Italy - 2013)

"The elms after 100 years of Dutch Elm disease"

Guest Editors: A. Santini, L. Ghelardini, E. Collin, A. Solla, J. Brunet, M. Faccoli, A. Scala, S. De Vries, J. Buiteveld

\section{Dutch elm disease and elm bark beetles: a century of association}

\author{
Alberto Santini ${ }^{(1)}$, Massimo Faccoli ${ }^{(2)}$
}

Bark beetles of the genus Scolytus Geoffroy are the main vectors of the fungus Ophiostoma ulmi s.l., which causes the Dutch elm disease. The large and small elm bark beetles - S. scolytus (F.) and S. multistriatus (Marsham), respectively - are the most common and important species spreading the pathogen worldwide. The success of the pathogen-insect interactions is mainly due to the characteristic reproductive behavior of the elm bark beetles, which, however, largely depends on the occurrence of infected trees. During feeding activity on elm twigs, callow adults carrying pathogen conidia on their bodies contaminate healthy trees and facilitate pathogen development and movement within the wood vessels. Infected trees become then suitable for insect breeding in the stem bark. This well-known mutualistic association has devastating consequences for elm survival. Although much is known about insect-pathogen interactions and transmission mechanisms, many topics still deserve additional attention, as, for example, beetle systematic based on new molecular tools and morphological characters; selection of European elm clones based on disease avoidance; consequences of global warming on life-history of the three organisms (fungus-insect-tree) involved in the pathosystem; new problems resulting from the rapid increase of international trade among continents, leading to the accidental introduction of new vector species or new pathogen species or races, or to the introduction of new highly susceptible elm species in gardens and public parks. A holistic approach to tackle the problem is highly recommended, taking into account how these organisms interact with each other and the environment, and how their interactions could be modified in order to face one of the most destructive diseases ever known in plant pathology.

Keywords: Dutch Elm Disease, Elm Bark Beetles, Scolytus-Ophiostoma Interactions, DED Cycle, Avoidance Mechanisms, Disease Escape, Resistance

\section{Introduction}

Dutch elm disease (DED), caused by some Ascomycete fungi of the genus Ophiostoma (Ophiostoma ulmi s.l.), is one of the most destructive diseases of woody trees ever known in plant pathology. The severity and devastation of its pandemics stirred up the interest of public opinion and researchers (Rohring 1996). Since prehistory, elms (Ulmus spp.) are strictly linked to human acti-

vities, providing a number of different forest, agricultural and cultural services. DED spreading and infection of suitable hosts is mainly due to a synchrony between life cycles of host-tree, pathogen and elm bark beetles (Coleoptera: Curculionidae, Scolytinae), the main fungus vectors. Such a synchrony allows the insect vectors to spread the pathogen when host plants are more prone to be infected and temperatures are favorable to

(1) Institute of Sustainable Plant Protection, CNR, v. Madonna del Piano 10, I-50019 Sesto Fiorentino (FI - Italy); (2) Department of Agronomy, Food, Natural Resources, Animals and Environment (DAFNAE), Agripolis, v.le dell'Università 16, I-35020 Legnaro (PD - Italy)

@ Alberto Santini (a.santini@ipp.cnr.it)

Received: Jan 02, 2014 - Accepted: May 18, 2014

Citation: Santini A, Faccoli M, 2015. Dutch elm disease and elm bark beetles: a century of association. iForest 8: 126-134 [online 2014-08-07] URL: http://www.sisef.it/

iforest/contents/?id=ifor1231-008

Communicated by: Marco Borghetti the fungus growth, enhancing the pathogen aggressiveness.

After a century since the beginning of the first pandemic of DED in Europe (Spierenburg 1921), and the introduction in the USA of one of its most effective vector, the small elm bark beetle Scolytus multistriatus (Chapman 1910), the amount of available scientific data is indeed vast and covers many aspects. The aim of the present paper is to provide a thorough review of the knowledge concerning the association between DED pathogens and vectors. Possible challenges for future research topics are also explored.

\section{Ophiostoma ulmi s.l. and Dutch elm disease}

As a result of DED, during the last century elms suffered major losses worldwide, with the near-total disappearance of adult trees in many European, Asian and North American areas. Two pandemics occurred. The first, caused by $O$. ulmi (Buisman) Nannfield, began in Europe in the 1910s (Spierenburg 1921) and rapidly devastated elm populations in Europe and, 20 years later, in North America (Brasier 2000, Guries 2001). Around 1940, the disease declined in Europe (Brasier 1979, Mittempergher 1989). A few years later, in the mid-1900s, a second and more destructive pandemic caused the widespread destruction of mature elms in Europe, Western Asia and North America (Gibbs \& Brasier 1973, Brasier \& Kirk 2001). This second still active pandemic is due to a different fungus species, the highly virulent $O$. novo-ulmi Brasier (Brasier 1991), which has almost totally replaced $O$. ulmi. Moreover, two subspecies of $O$. novo-ulmi are known: O. novo-ulmi ssp. novo-ulmi, previously known as the Euro-Asian race (EAN), and $O$. novo-ulmi ssp. americana, previously known as the North American race (NAN Brasier 1979, Brasier \& Kirk 2001). Since the 1980 s, the presence of hybrids has been detected between these two subspecies. The hybrids, whose pathogenicity does not differ from that of their parent subspecies (Santini et al. 2005b), are now expanding across the continents (Brasier \& Kirk 2010). A third species, O. himal-ulmi Brasier \& Mehrotra, which also causes DED, was identified in the Himalayas (Brasier \& Mehrotra 1995), but its presence has still not been reported in Europe or North America.

The destructiveness and severity of this disease is mainly due to the rapidity and efficiency of its spread, which is particularly quick and effective because $O$. ulmi s.l. has exploited an ancient association between the native saprotrophic species $O$. quercus and the elm bark beetles active in Europe prior to the arrival of O. ulmi (Brasier 1990). Various species of elm bark beetles are involved in the disease transmission. Callow bee- 
tles (i.e., sexually immature) emerge in spring from the bark of dying infected elms and fly to the crown of healthy elms to feed at the crotches of young twigs. Infected beetles contaminate healthy elms by carrying the pathogen spores into feeding wounds, in direct contact with the host's vascular tissues. Spores germinate into a growing mycelium and reach the xylem, where the pathogen moves into the vessels through a yeast multiplication phase (Webber \& Brasier 1984). Later on, the beetles move to dying elms, i.e., infected by $\mathrm{DED}$, to lay eggs in the inner bark of the stem and main branches, which provide an ideal environment for both larval development (Rudinsky 1962) and pathogen fructification (Webber \& Brasier 1984). The new contaminated beetles emerge from the bark and move toward the crown of new healthy elms, completing the cycle. The infection may also occur through root anastomoses between infected and healthy trees (Webber \& Brasier 1984).

Initial external symptoms of DED include crown discoloration and leaf wilting. Symptoms spread along branches centrally, affecting the entire crown, and the tree dies rapidly. A typical internal symptom of the disease is the formation of a brown ring in the infected sapwood due to the formation of tyloses and gels in the xylem vessels (Stipes \& Campana 1981, Rioux et al. 1998, Ouellette et al. 2004a, 2004b, Et-Touil et al. 2005), resulting in their obstruction (Zimmermann \& McDonough 1978, Newbanks et al. 1983). A systemic infection drastically re- duces the hydraulic conductivity in the functional xylem, resulting in a severe wilt syndrome which kills the tree rapidly (MacHardy \& Beckman 1973).

\section{Life history of the elm bark beetles}

Bark beetles belonging to the genus Scolytus Geoffroy are the main vectors of Ophiostoma ulmi s.l. (Webber \& Brasier 1984). Although about 10 species of Scolytus live on elms (Wood \& Bright 1992, Pfeffer 1995), the large and small elm bark beetles $S$. scolytus (F.) and S. multistriatus (Marsham), respectively - are the most common and important species spreading the pathogen worldwide (Webber \& Kirby 1983, Webber \& Brasier 1984, Webber \& Gibbs 1989, Webber 1990, Webber 2000, Faccoli 2001, 2004).

Many species of elms have been recorded as potential elm bark beetle hosts, both in the insects' native distribution range and in countries of new introduction (Balachowsky 1949, Stark 1952, Michalski 1973, Wood \& Bright 1992, Pfeffer 1995). Elm bark beetles attack trees dying, stressed or weakened by different factors (e.g., drought, diseases, pruning, defoliations). Mature beetles identify potentially suitable hosts by a blend of volatiles released by damaged or diseased elms (Meyer \& Norris 1967, Pearce et al. 1975). Following initial attacks by the pioneer beetles, most of the insect populations find the suitable hosts in response to a blend of aggregation pheromones released by conspeci-

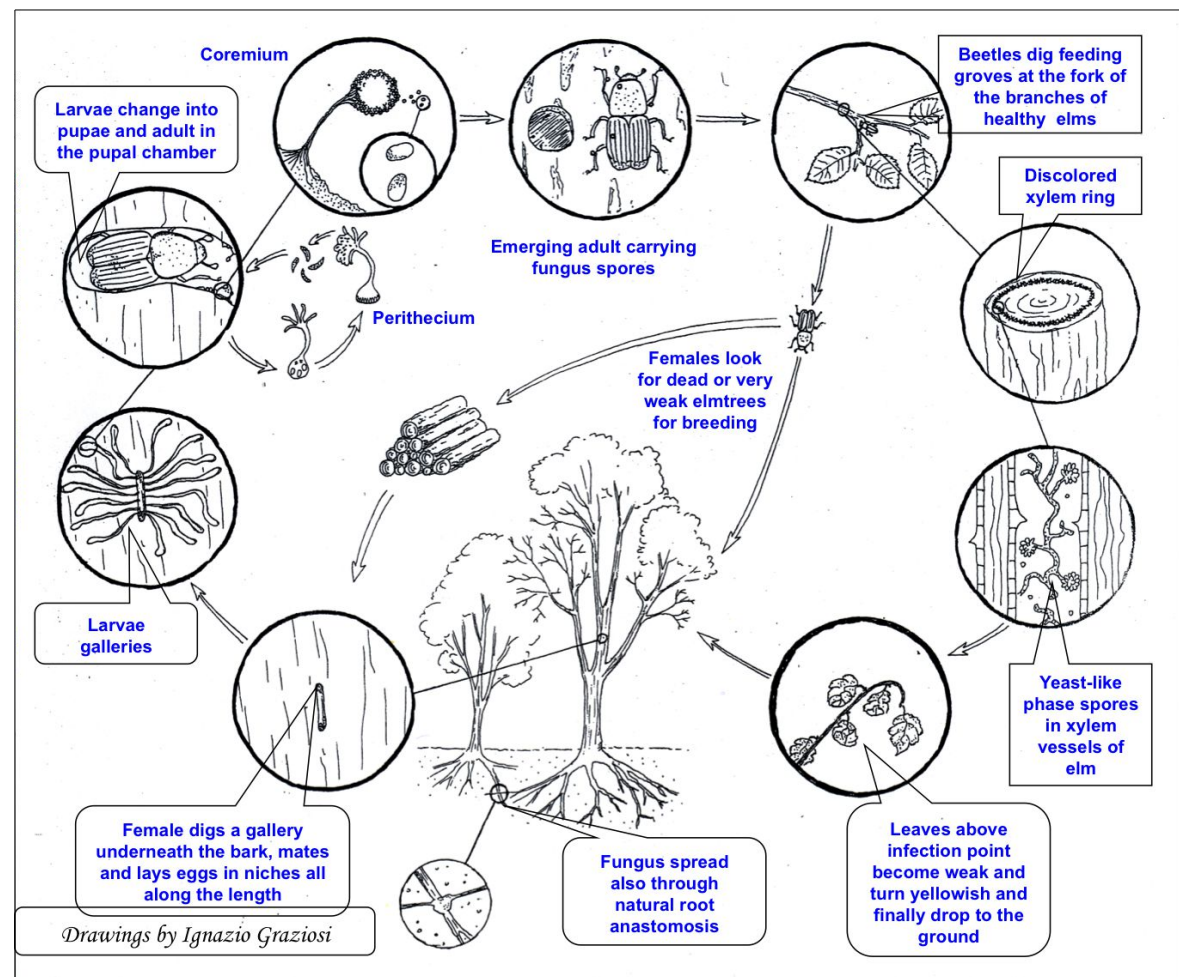

Fig. 1 - Dutch elm disease cycle (modified from Ghelardini \& Santini 2009). fic insects (Pearce et al. 1975, Wood 1982, Faccoli 2004), assuring the whole bark colonization (Peacock et al. 1971).

Elm bark beetles usually lay eggs in the phloem of weakened trees (Fig. 1). After finding and acceptance of the host, elm bark beetle females bore an entrance hole through the tree bark, communicating with a small mating (or nuptial) chamber excavated in the phloem, where mating occurs (Fransen 1939, Svihra \& Clark 1980). Each mated female excavates a maternal tunnel (or egg gallery) in the phloem where eggs are laid along both sides. The maternal galleries run parallel to the wood fibers, without ramifications (Sinclair \& Campana 1978, Burdekin 1979, Agrios 1988). Construction of the maternal tunnels and egg-laying take about three weeks (Betrem 1929). Larvae hatch about one week after oviposition, and immediately begin to bore characteristic larval galleries developing in an orthogonal direction from the maternal ones (Balachowsky 1949, Burdekin 1979, Agrios 1988). Larval galleries of Scolytus spp. are $60-150 \mathrm{~mm}$ long on average and they cross each other only rarely (Betrem 1929, Buisman 1932, Manojlovic \& Sivcev 1995, Kletecka 1996). Larval tunnels become wider as the larvae develop and move away from the maternal gallery (Betrem 1929). Larvae feed in the phloem for about 30 days, passing through 5 developing instars before becoming fully grown (Fransen 1939). Shortly before pupation, mature larvae bore a pupal chamber in the external part of the sap-wood, where they metamorphose first into pupae (Webber \& Brasier 1984, Webber 1990) and after about two weeks into adults (Zanta \& Battisti 1990). The new callow adults then emerge from the bark of the host tree through a hole excavated directly from the pupal chamber (Kletecka 1996). After emergence, adults fly and disperse looking for healthy trees on which they carry out the sexual maturation feeding. Elm bark beetles may be mono- or bivoltine. In favorable climatic conditions there are usually two generations per year (Della Beffa 1949), the first starting in late spring (May-June) and emerging in late summer (August-September), the second beginning in autumn (September) overwintering as larvae, and emerging in the following spring (Betrem 1929, Buisman 1932, Fransen 1939, Lanier \& Peacock 1981, Zanta \& Battisti 1990).

In all monogamous bark beetle species, before reproducing in the bark of dying trees, the newly emerged callow adults need a period of sexual maturation reached by feeding in crotches of 2-3 years old twigs of healthy and vigorous elms. The maturation feeding lasts a few days, during which the insects excavate short tunnels (2-4 cm long) in the twig phloem and sapwood (Fransen 1939, Webber \& Brasier 1984). Twig feeding, 
which is a prerequisite for sexual maturation of callow adults, is associated also with restoration of the beetle reserves (food and water - Fransen 1939, Svihra \& Clark 1980 Lanier \& Peacock 1981, Heybroek et al 1982, Lunderstadt \& Rohde 1993). Although Scolytus beetles prefer twigs occurring on the upper part of the crown (Svihra \& Clark 1980, Webber \& Kirby 1983), feeding tunnels can be made in almost any young and sappy bark (Fransen 1939, Lanier \& Peacock 1981, Webber \& Kirby 1983). Scolytus beetles can stay in the feeding tunnels for up to 13 days (Fransen 1939). When sexual maturity is reached, adults fly away looking for weakened trees in which they lay eggs and start a new generation.

\section{Interactions among elms, DED fungi and elm bark beetles}

The mechanisms of pathogen transmission were deeply investigated in the past (Webber $\&$ Brasier 1984). Some authors considered the wind to be important in spreading fungal spores from infected plants to tissues of healthy trees exposed by wounds or pruning (Westerdijk \& Buisman 1929, Smucker 1935). This hypothesis, however, was soon disproved, as anemochoral dispersion of the spores would be too casual and generic, and could not ensure ideal growing conditions to the pathogen for a rapid development (Goidanich \& Goidanich 1937).

Other authors suggested the rain as the main responsible of the conidial spread, allowing them to reach the leaf stomata (Schwarz 1922). However, in 1927 Marchal proposed that bark beetles could be vectors of O. ulmi s.l., as they migrate between infected and healthy elms (Marchal 1927). Although the pathogen may be transmitted effectively in several ways (Schwarz 1922, Westerdijk \& Buisman 1929, Smucker 1935), elm bark beetles belonging to the genus Scolytus were found to be the most effective pathogen vectors (Marchal 1927, Fransen 1931, Jacot 1934, 1936, Collins et al. 1936, Webber \& Brasier 1984, Webber 1990, Basset et al. 1992, Favaro \& Battisti 1993, Battisti et al 1994, Faccoli \& Battisti 1997, Faccoli et al 1998, Faccoli 2004). The definitive demonstration of Marchal's theory was provided by Fransen (1931) and Fransen \& Buisman (1935), who showed pathogen presence and proliferation in the short galleries bored by elm bark beetles in healthy plants during maturation feeding. Many other vectors were later identified, mainly mites and insects living on elms, but none as effective as bark beetles (Jacot 1934, 1936, Collins et al. 1936).

Elm bark beetles originally had a mutualistic ectosymbiosis with the indigenous saprotrophic fungus $O$. quercus, previously known as the hardwood biological species group, or OPH group, of $O$. piceae (Brasier
1990). Later, the arrival in Europe of the congeneric $O$. ulmi s.l., a fungus having niche requirements similar to $O$. quercus but far more aggressive, caused the complete replacement of the endemic fungus. The new association became an effective DED transmission pathway, with devastating consequences for elm survival.

The success of the pathogen-insect interactions is mainly due to the characteristic reproductive behavior of the elm bark beetles, and largely depends on the occurrence of $O$. ulmi infected trees. The feeding activity of callow adults emerged from infected trees, and carrying pathogen conidia on their bodies, contaminates healthy trees and facilitates consequent development and movement of the pathogen within their wood vessels (Fransen \& Buisman 1935, Goidanich 1936, Goidanich \& Goidanich 1937, Gibbs 1974, Burdekin 1979, Webber \& Kirby 1983, Webber \& Brasier 1984). Basset et al. (1992) showed that a contact for at least 72 hours between infected beetles and xylem can be sufficient for the pathogen transmission. This is known as the pathogenic phase of the disease (Lea 1977, Gibbs \& Smith 1978). The canopy of every tree may host several dozen callow adults, and the process can be repeated for several years; thus, healthy trees growing close to elms infected by $O$. ulmi s.l. and infested by elm bark beetles are exposed to a very high risk of infection. This transient phase is very important for pathogen spread, as it is the only way for the fungus to reach and infect isolated trees. Maturation feeding and pathogen infection weaken trees that will become attractive for mature reproductive adults of the following insect generations, which will be looking for dying (i.e., diseased) elms where to lay eggs in the bark of trunk and main branches. During bark infestation and excavation of the mating galleries, the mature adults again infect the hosts with the conidia carried on their tegument, fulfilling their role as vectors for a second time. Bark colonization by insects and pathogen on already infected elms (from the twigs) is known as the saprophytic phase of the disease (Lea 1977, Gibbs \& Smith 1978). In this respect, maternal galleries and pupal chambers are an ideal micro-environment for both fungal growth and sporulation (Webber \& Brasier 1984). Interestingly, in this phase two fungus isolates having different origins, one from previous maturation feeding and the other from the more recent bark colonization, may meet in the same tree. This gives to the pathogen more chances of sexual reproduction, being $O$. ulmi s.l. an obliged outcrossing fungus. The emerging beetle offspring developed in the phloem of infected trees will become new vector of fungal conidia and the dispersal cycle will start again (Webber \& Brasier 1984). Not every wound due to maturation feeding results, however, in pathogen transmission (Fransen 1939). Parker et al. (1941) reported that $13 \%$ of all cases resulted in tree infection, whereas Webber \& Brasier (1984) found that about $30 \%$ of feeding wounds were infected by $O$. ulmi s.l. Xylem infection may be a result either of a primary and direct spore transfer from the beetle into the xylem vessels or, more likely, of a secondary infection due to earlier pathogen colonization of the feeding wound followed by subsequent growth into the xylem tissues (Buisman 1932).

\section{Host resistance}

There is considerable variation among elm species in host resistance to DED. Asian elms are usually the most resistant (Smalley \& Kais 1966, Ware 1995, Smalley \& Guries 2000), while most North American elms are highly susceptible and European species are moderately to very susceptible (Gibbs 1978, Dunn 2000)

Compared with susceptible elms, both at species and individual level, naturally resistant elms show some peculiar anatomical features such as smaller $(\mathrm{McNabb}$ et al. 1970, Sinclair et al. 1975, Solla \& Gil 2002a, 2002b, Solla et al. 2005b) and shorter vessels (Elgersma 1970, Ewers et al. 1990, Tyree \& Zimmermann 2002), smaller pit membrane diameter and pit aperture area, lower pit membrane abundance per vesselwall, smaller ray width and ray tangential area (Martín et al. 2009). Anatomical features, however, show much variability also between and within species. For instance, the mean maximum vessel length and diameter are significantly higher in U. minor than in $U$. minor $\mathrm{x}$ pumila, and these differences increase with age (Martin et al. 2013).

Induced resistance to DED is associated strictly with the host's capacity to quickly localize the infection, preventing the pathogen from spreading in the vascular system (Sinclair et al. 1975) and reaching the cambium (Shigo \& Tippet 1981, Bonsen et al. 1985). Reactions taking place as a consequence of the infection may include vessel closing by tyloses, embolisms, accumulation of pectin and hemicelluloses (Elgersma 1982, Shigo 1982, Ouellette \& Rioux 1992, Rioux et al. 1998), synthesis of chemicals such as phytoalexin-like sesquiterpenes (Jeng et al. 1983, Duchesne et al. 1985, Sticklen et al. 1991), and formation of histological barriers typically containing phenols and suberin (Rioux \& Ouellette 1991a, 1991b, Ouellette et al. 2004a, 2004b, Et-Touil et al. 2005).

Elm susceptibility to DED shows strong seasonal variation in both resistant and susceptible species. The period of highest susceptibility and its duration, i.e., the period during which trees can easily become infected varies greatly among elm species and even among elm populations and experimen- 
tal conditions (Banfield 1941, 1968, Pomerleau 1965,1968 , Neely 1968, 1970, Smalley 1963, Tchernoff 1965, Smalley \& Kais 1966, Santini et al. 2005a, Solla et al. 2005a). According to studies correlating susceptibility to $O$. ulmi s.l. with seasonal host phenology (Pomerleau 1965, Neely 1968 1970, Takai \& Kondo 1979, Solla et al 2005a, Santini \& Ghelardini, unpublished data), the period of highest susceptibility coincides with the seasonal maximum growth rate, recorded at the beginning of leaf expansion and formation of large spring xylem vessels, all genotype-dependent characters The decrease in susceptibility observed from spring to late summer is also correlated to the seasonal changes in wood anatomy, i.e. the transition from early wood, characterized by large vessel elements, to late wood, made up of smaller cells with thicker cell walls (Pope 1943, Solla et al. 2005a). Pathogen development is, hence, highly dependent on the host's seasonal morphogenesis and cambial activity, as well as on the pattern of longitudinal and radial growth of the host plant Because efficient wood compartmentalization forces the plant to keep building new barriers, which limit the accessibility of its own reserves in the stem (Bonsen et al 1985), the highest susceptibility occurs with low energy reserves, high growth rate, not fully efficient photosynthesis and large ves sels (Ghelardini \& Santini 2009). Since plant physiological processes are seasonally regulated, and elms are exposed to fungus inoculation only in a transitory and short phase of the vector life history (twig-crotch feeding phase), the infection will occur only if insect feeding phase and time of host susceptibility overlap. Thus, an asynchrony between these phenological phases may allow trees to avoid infection, representing a particular form of disease-escape resistance. For instance, although inoculated in the same day in central Italy, southern European clones of $U$. minor showed fewer disease symptoms than northern ones, with a significant direct relationship between disease severity and bud burst date (Santini et al. 2005a). As southern clones cultivated in central Italy flushed significantly earlier than northern ones (Ghelardini et al. 2006), this suggest that, at the inoculation date, the southern clones had already passed the period of maximum susceptibility, which for European elms begins 40-50 days after bud burst and lasts for a number of days related to environmental conditions and genotype (Tchernoff 1965, Smalley \& Kais 1966, Santini \& Ghelardini, unpublished data). Southern clones completed the formation of the large spring vessels and the production of latewood early, reducing their risk of infection (Pope 1943, Solla et al. 2005a, Santini \& Ghelardini, unpublished data). These studies provided new information on susceptibility to DED, sug- gesting that early flushing is a mechanism of DED avoidance based on asynchrony between maximum susceptibility period and inoculation time (Santini et al. 2005a).

Variations in tree susceptibility related to different growth rhythms, caused by either seasons or differences in elm populations or clones (Sutherland \& Brasier 1997), fit well with the growth-differentiation balance hypothesis (Herms \& Mattson 1992). This hypothesis provides a framework for predicting how plants balance resource allocation between differentiation-related processes and growth-related processes over a range of environmental conditions, as it is known that resources cannot be allocated to both functions simultaneously (Lorio 1986). Resource availability is high in spring, when favorable temperatures are combined with plentiful water supply, a condition lasting for a short time in the Mediterranean climate until the early, hot and dry summer occurs. At this time of the year, elm energy reserves are already exhausted by the flowering process that occurs in late winter, and by the construction of the new porous ring, which has to provide nutrients for the expanding photosynthetic surfaces. Growing meristems behave as strong photosynthetic sinks, provisioned by carbon sources that include neighboring mature leaves (Marcelis 1996) and also newly formed leaves. No resources are dedicated to defense, which make elms especially susceptible to DED during spring, exactly in the period of the vector's inoculative phase. As time passes, resource availability and growth rate decrease so that photosynthates can be allocated to differentiation. This process could explain why inoculations by the second beetle generation in summer which furthermore accounts for a lower percentage of vectors (Faccoli \& Battisti 1997) - is less effective or totally ineffective in pathogen transmission compared to the first generation in spring. Because in early-flushing elms these phenological and physiological events occur earlier in spring, the emerging beetles will feed on trees having already mature leaves able to allocate carbohydrates to secondary metabolism, and therefore better defend against pathogen infections. In this period early-flushing elms are also already producing latewood that, being constituted of small and scattered vessels with a greater proportion of fibers, is less suitable for spore diffusion.

\section{Challenges for the nearby future}

Although we are learning much about insect-pathogen interactions and transmission mechanisms, many topics still deserve additional attention.

The systematic of species belonging to the genus Scolytus is one of the most complicated amongst bark beetles (Michalski 1973, Pfeffer 1995). The systematic position of elm bark beetle species must be better defined by sequencing specific regions of the DNA in phylogenetic studies, to provide a correct identification of the Scolytus species, as already done with other scolytid genera (Chang et al. 2014). Genetic improvement programs are also required on the host trees aiming to select new European elm clones with higher levels of DED resistance, based, for instance, on the bud-burst precocity (Santini et al. 2005a). This resistance could be exploited by specific studies exploring how different climatic conditions affect budburst date and growth rhythm, and the natural history (i.e., phenology and voltinism) of Scolytus spp. (Ghelardini \& Santini 2009). Early flushing European elm clones could be selected to obtain elms avoiding natural infection through an asynchrony between host and insect phenology, both of which are regulated by temperature (Sinclair \& Campana 1978, Sengonca \& Leisse 1984, Ghelardini et al. 2010). Although many studies were conducted to select elm species and clones resistant to $O$. ulmi s.l. (Smalley \& Guries 2000, Mittempergher \& Santini 2004), no effort was made to identify mechanisms of combined resistance to both DED and elm bark beetles. Concerning pathogens, considerable progress has been made in genetic and systematic knowledge of the Ophiostoma species associated with elm bark beetles (Kirisits 2013). The significance of the association, however, is still matter of discussion, especially regarding the role of fungi - and spore load carried by the beetles - in exhausting tree defenses, the relations between fungus pathogenicity and beetle aggressiveness, and their role in the tree killing process.

There have been very few morphological studies on the Ulmus-Ophiostoma-Scolytus system. Concerning insects, the structure and ultra-structure of the mycangia or mycetangia on the bark beetle tegument was deeply investigated in the past (Francke-Grosmann 1956a, 1956b, 1963a, 1963b, 1967, Batra 1963, Beaver 1989, Berryman 1989, Lévieux et al. 1991), but not specifically in the Scolytus species except for a few preliminary observations (Faccoli 1995). The host-pathogen interactions leading to DED symptoms were recently analyzed in vitro by histo- and cyto-chemical tests. Callus cultures of susceptible $U$. americana were inoculated with the highly aggressive pathogen $O$. novoulmi. Inoculated callus tissues were then compared with water-treated callus tissues using TEM and SEM light microscopy. New aspects of these interactions were described, including histological observations - for the first time in plant callus cultures - on suberin, with its typical lamellar structure, and the intracellular presence of $O$. novo-ulmi (Aoun et al. 2009). Other SEM applications were the description of the typical tyloses in- 
duced by the pathogen within the spring vessels of infected elms, or the tissue invasion process operated by blastoconidia (Elgersma 1973, Elgersma \& Heybroek 1979). However, the studies were limited to a simple description of the host reactions to pathogen attacks, and did not investigate the structure of the reaction tissues.

Chemical communication is of crucial importance to manage insect populations, DED epidemics and their damage to elms. Gaps in our knowledge concern, for instance, the selection mechanisms driving callow adult beetles in the plant choice for maturation feeding. In this phase, tree attractiveness to elm bark beetles is of primary importance for a susceptible plant to be infected by $O$. ulmi s.l. Therefore, once the chemical attractant has been identified a specific marker assisted tree-breeding program may be developed for both native European and American elm species. Such a tree-breeding strategy would avoid the use of Asian species as source of resistance, as they could become invasive, posing a threat to the native biodiversity ( $\mathrm{Za}$ lapa et al. 2009, Brunet et al. 2013).

Because the number of papers published on different Scolytus species is directly related to the economic importance of the organisms, only biology and ecology of the most harmful species were investigated, while very little is known about the less common species - such as $S$. laevis, S. sulcifrons and $S$. triarmatus - which, however, are recently showing an increasing importance as DED vectors. There is hence a dramatic lack of detailed information on less damaging species, although it would be very useful for comparison and generalization, and would certainly also lead to a better understanding of the reasons for the aggressiveness of the dangerous species. There is, therefore, a wide and regrettable gap in our knowledge concerning secondary, or less common, Scolytus species.

Research is also needed about the environmental factors affecting elm bark beetles and pathogen performance and their adaptation to new and changing environments, especially in relation to global change. New problems can emerge from climate change that modify the geographic distributions of pests, pathogen and hosts. Although the northward and upward spread of both DED epidemics and some Scolytus species (e.g., S. multistriatus in southern Sweden (Faccoli 2003, pers obs., - or at higher altitudes on Apennines, Pecori et al. 2013) was recently associated to global warming, considerable knowledge gaps exist regarding the effects of these factors on insect aggressiveness and fungus pathogenicity in both Europe and North America. Very little information is also available regarding the relations between global change and tree resistance, although this topic represents a considerable component of modern researches. Characterizing the physiological status of trees in relation to their susceptibility is also needed prior to building risk prediction models in non-epidemic areas, such as Northern Europe and America. What will the responses be of elms, DED and elm bark beetles to increasing temperatures? In $U$. minor a large intra-specific variation in timing of bud burst was found to be mainly dependent on geographic origin. The bud burst date was directly related to latitude and altitude, i.e., temperature, with a greater chilling requirement for dormancy in northern areas or highlands than in southern or lowlands (Ghelardini et al. 2006). It can be hypothesized, for instance, that under climate warming European elms would start to flush earlier in most parts of their natural range, maybe escaping the pathogen infection (Santini et al. 2004, Ghelardini et al. 2010), but how the insect phenology will change in front to a warmer climate? The few models describing the population dynamics of pathogen and insects consider climatic conditions only marginally. They are generally never focused on changing environments, nor on the prediction of future impacts in new areas or on new elm species, as recently observed in Colorado following the introduction of the banded elm bark beetle, S. schevyrewi Semenov from Siberia (Jacobi et al. 2007). Studied carried out at larger geographic scale should hence lead to more dynamic models.

Some factors suspected to be of secondary importance in the epidemic dynamics of DED were in the past largely underestimated. The case of natural enemies of the elm bark beetles should be, for instance, valuable for further research. Similarly, apart a few studies concerning the unattractiveness of $U$. laevis toward the Scolytus beetles (Sacchetti et al. 1990), neither the effects of intra- and inter-specific variations in the nutritional quality of elms nor the tree constitutive defenses against elm bark beetles were considered. Research on genetic variations in beetle/pathogen populations, especially by comparing endemic and epidemic areas, should also provide very useful information on their role in epidemic dynamics. Moreover, the possible occurrence and importance of transmission mechanisms different than those due to elm bark beetle maturation feeding or the occurrence of other possible vectors were incompletely explored (Covassi \& Masutti 1980). For instance, the high efficiency of $S$. scolytus in spreading DED was recently suggested to be partly due to its association with two mites, Proctolaelaps scolyti Evans and Tarsonemus crassus (Schaarschmidt), and the hyperphoretic spores of $O$. novo-ulmi they carry (Moser et al. 2010). Another challenge concerns the emergence of new problems resulting from the rapid increase of international trade among continents, leading to the accidental introduction of new vector species, or new highly pathogenic strains, or new highly susceptible elm species in gardens and public parks. Introductions of new pathogens or vectors, for instance, may lead to new and unexpected associations, able to increase the fitness of both organisms with tremendous consequences for the host populations, as recorded in other insect-fungus associations (Battisti et al. 1999, Luchi et al. 2012).

\section{Conclusion}

The processes that regulate the current beetle-fungus symbiosis remain poorly understood. The relationships between elm bark beetles and $O$. ulmi s.l. depend on several factors, such as the climatic and environment characteristics, and the interactions between the components of the biotic community, including, for example, the d-factor, a citoplasmically transmitted virus disease of Ophiostoma ulmi s.l. (Brasier 1983). Commonly to other bark beetle-fungus symbiosis, all these factors play important roles in determining composition, fidelity and longevity of the association between beetles and DED fungi (Six 2012).

Insects play a role of primary concern in transmitting diseases to elms, like for instance several species of leaf-hoppers identified as vectors of the elm yellow phytoplasma (Carraro et al. 2004).

There are thus several aspects that still deserve to be studied for a better understanding of the pathogen-insect interactions. In addressing these issues, a holistic approach is highly recommended, taking into account all the many factors affecting pathogen transmission and disease spread.

\section{References}

Agrios GN (1988). Plant diseases caused by fungi. In: "Plant Pathology". Academic Press, S. Diego, CA, USA, pp. 265-509.

Aoun M, Rioux D, Simard M, Bernier L (2009). Fungal colonization and host defense reactions in Ulmus americana callus cultures inoculated with Ophiostoma novo-ulmi. Phytopathology 99: 642-650. - doi: 10.1094/PHYTO-99-6-0642 Balachowsky A (1949). Faune de France $n^{\circ} 50$ : Coléoptères Scolytides. Libraire de la Faculté des Sciences, Lechevalier, Paris, France, pp. 320. [in French]

Banfield WM (1941). Distribution by the sap stream of spores of three fungi that induce vascular wilt diseases of elm. Journal of Agricultural Research 62: 637-681.

Banfield WM (1968). Dutch elm disease recurrence and recovery in American elm. Phytopathologische Zeitschrift 62: 21-60. - doi: 10.1111/ j.1439-0434.1968.tb02345.x

Basset Y, Favaro A, Springate ND, Battisti A (1992). Observations on the relative effectiveness of Scolytus multistriatus (Marsham) and Scolytus pygmaeus (Fabricius) (Coleoptera, Sco- 
lytidae) as vectors of the Dutch Elm Disease. Bulletin de la Société Entomologique Suisse 65 61-67.

Batra LR (1963). Ecology of ambrosia fungi and their dissemination by beetles. Transactions of the Kansas Academy of Science 66: 213-236. doi: $10.2307 / 3626562$

Battisti A, Favaro A, Faccoli M, Masutti L (1994). Suscettibilità dei ceppi di Ulmus sp. all'attacco primario di Scolytus sp.pl. (Coleoptera, Scolytidae) [Susceptibility of Ulmus species to primary infestation of Scolytus species (Coleoptera, Scolytidae)]. In: "Innovazioni e Prospettive nella Difesa Fitosanitaria" (Istituto Sperimentale di Patologia Vegetale, Roma). Convegno MiRAAF, Ferrara, Italy, pp. 351-354. [in Italian]

Battisti A, Roques A, Colombari F, Frigimelica G, Guido M (1999). Efficient transmission of an introduced pathogen via an ancient insect-fungus association. Naturwissenschaften 86: 479-483. doi: $10.1007 /$ s001140050658

Beaver RA (1989). Insect-Fungus Relationships in the Bark and Ambrosia Beetles. In: Proceedings of the $14^{\text {th }}$ Symposium of the Royal Entomological Society of London / British Mycological Society "Insect-Fungus Interactions" (Wilding N, Collins NM, Hammond PM, Webber JF eds). Academic Press, London, UK, pp. 121-143.

Berryman AA (1989). Adaptive pathways in scolytid-fungus associations. In: Proceedings of the $14^{\text {th }}$ Symposium of the Royal Entomological Society of London / British Mycological Society "Insect-Fungus Interactions" (Wilding N, Collins NM, Hammond PM, Webber JF eds) . Academic Press, London, UK, pp. 145-160

Betrem JG (1929). De iepenziekte en de iepenspintkevers [The elm disease and elm bark beetles]. Tijdschr Plantenziekten 35: 272-289. [in Dutch] - doi: 10.1007/BF02810222

Bonsen KJM, Scheffer RJ, Elgersma DM (1985). Barrier zone formation as a resistance mechanism of elms to Dutch elm disease. IAWA Bulletin 6: 71-77. - doi: 10.1163/22941932-90000 916

Brasier CM (1979). Dual origin of recent Dutch Elm disease outbreaks in Europe. Nature 281: 78-79. - doi: 10.1038/281078a0

Brasier CM (1983). A citoplasmically transmitted disease of Ceratocystis ulmi. Nature 305: 220 223. - doi: 10.1038/305220a0

Brasier CM (1990). China and the origins of Dutch elm disease: an appraisal. Plant Pathology 39: 5-16. - doi: 10.1111/j.1365-3059.1990.tb0247 0.X

Brasier CM (1991). Ophiostoma novo-ulmi sp. nov., causative agent of current Dutch elm disease pandemics. Mycopathologia 115: 151-161. doi: 10.1007/BF00462219

Brasier CM (2000). Intercontinental spread and continuing evolution of the Dutch elm disease pathogens. In: "The elms: breeding, conservation and disease management" (Dunn CP ed). Kluwer Academic Publishers, Dordrecht, The Netherlands. pp. 61-72.

Brasier CM, Kirk SA (2001). Designation of the EAN and NAN races of Ophiostoma novo-ulmi as subspecies: their perithecial size differences and geographical distributions. Mycological Research 105: 547-554. - doi: 10.1017/S0953756 201004087

Brasier CM, Kirk SA (2010). Rapid emergence of hybrids between the two subspecies of Ophiostoma novo-ulmi with a high level of pathogenic fitness. Plant Pathology 59: 186-199. - doi: 10.11 11/j.1365-3059.2009.02157.x

Brasier CM, Mehrotra MD (1995). Ophiostoma himal-ulmi sp. nov., a new species of Dutch elm disease fungus endemic to the Himalayas. Mycological Research 99: 205-215. - doi: 10.1016/S 0953-7562(09)80887-3

Brunet J, Zalapa JE, Pecori F, Santini A (2013). Hybridization and introgression between the exotic Siberian elm, Ulmus pumila, and the native Field elm, $U$. minor, in Italy. Biological Invasions 15: 2717-2730 - doi: 10.1007/s10530-0130486-z

Buisman C (1932). De olmen- of iepenziekte [The elms and elm disease]. Dirix-Van Riet K, Antwerpen, Belgium, pp. 15. [in Dutch]

Burdekin D (1979). Beetle and fungus: the unholy alliance. Heinemann, London, UK, pp. 65-79.

Carraro L, Ferrini F, Ermacora P, Loi N, Martini M, Osler R (2004). Macropsis mendax as a vector of elm yellows phytoplasma of Ulmus species. Plant Pathology 53: 90-95. - doi: 10.1111/ j.1365-3059.2004.00940.x

Chang H, Liu Q, Hao D, Liu Y, An Y, Qian L, Yang X (2014). DNA barcodes and molecular diagnostics for distinguishing introduced Xyleborus (Coleoptera: Scolytinae) species in China. Mitochondrial DNA 25: 63-69. - doi: 10.3109/ 19401736.2013.779260

Chapman JW (1910). The introduction of an European scolytid, the smaller bark beetle, Scolytus multistriatus (Marsham) into Massachusetts. Psyche 17: 63-68. - doi: 10.1155/1910/ 76129

Collins CW, Buchanan WD, Witten RR, Hoffman $\mathrm{CH}$ (1936). Bark beetles and other possible insect vectors of Dutch elm disease Ceratostomella ulmi (Schwarz) Buisman. Journal of Economic Entomology 29: 169-176.

Covassi M, Masutti L (1980). Generalità sull'entomofauna degli olmi con particolare riguardo ai coleotteri scolitidi vettori della grafiosi [Review of the elm entomofauna with particular regard to bark beetles vectors of DED]. Informatore Fitopatologico 30: 19-26. [in Italian]

Della Beffa G (1949). Gli insetti dannosi all'agricoltura e i moderni mezzi e metodi di lotta [The insects harmful to agriculture and the modern control means and methods]. Hoepli, Milano, Italy, pp. 978. [in Italian]

Duchesne LC, Jeng RS, Hubbes M (1985). Accumulation of phytoalexins in Ulmus americana in response to infection by a nonaggressive strain of Ophiostoma ulmi. Canadian Journal of Botany 63: 678-680. - doi: 10.1139/b85-086

Dunn CP (2000). The elms: breeding, conservation and disease management. Kluwer Academic Publishers, Boston, USA, pp. 228.

Elgersma DM (1970). Length and diameter of xylem vessels as a factors in resistance of elms to
Ceratocystis ulmi. Netherlands Journal of Plant Pathology 76: 179-182 - doi: 10.1007/BF01974 328

Elgersma DM (1973). Tylose formation in elms after inoculation with Ceratocystis ulmi, a possible resistance mechanism. Netherlands Journal of Plant Pathology 79: 218-220. - doi: 10.1007/ BF01974237

Elgersma DM (1982). Susceptibility and possible mechanisms of resistance to Dutch elm disease. In: Proceedings of the "Dutch elm disease symposium and workshop" (Kondo ES, Hiratsuka Y, Denyer WBG eds). Winnipeg (Canada) 5-9 October 1981, pp. 169-177.

Elgersma DM, Heybroek HM (1979). Spread and survival of an aggressive and a non-aggressive strain of Ophiostoma ulmi in elms. Netherlands Journal of Plant Pathology 85: 235-240. - doi: 10.1007/BF01977595

Et-Touil A, Rioux D, Mathieu FM, Bernier L (2005). External symptoms and histopathological changes following inoculation of elms putatively resistant to Dutch elm disease with genetically close strains of Ophiostoma. Canadian Journal of Botany 83: 656-667. - doi: 10.1139/b05-037

Ewers FW, Fisher JB, Chiu ST (1990). A survey of vessel dimensions in stems of tropical lianas and other growth forms. Oecologia 84: 544-552. - doi: 10.1007/BF00328172

Faccoli M (1995). Coleotteri scolitidi e grafiosi dell'olmo. Prove di controllo combinato [Elm bark beetles and the Dutch elm disease: trials of combined control]. Master thesis in Forest Sciences, University of Padua, Italy, pp. 79. [in Italian]

Faccoli M (2001). Elm bark beetles and Dutch elm disease: tests of combined control. Journal of Pest Science 74: 22-29. - doi: 10.1046/j.14390280.2001.00033.x

Faccoli M (2004). Scolytus scolytus (F.). In: "Crop Protection Compendium 2004 Edition". CAB International, Wallingford, UK, CD-ROM. Faccoli M, Battisti A (1997). Observations on the transmission of Ophiostoma ulmi by the Smaller Elm Bark Beetles (Scolytus spp.). In: Proceeding of the IUFRO meeting "Integrating cultural tactics into the management of bark beetles and reforestation pest". Vallombrosa (Italy) 1-4 Sep 1996. General Technical Report NE-236, USDA Forest Service, pp. 172-176.

Faccoli M, Zanocco D, Battisti A, Masutti L (1998). Chiave semplificata per la determinazione degli Scolytus Geoffroy (Coleoptera Scolytidae) italiani viventi sugli olmi [Morphological key for determination of the Italian elm bark beetles of the genus Scolytus Geoffroy (Coleoptera Scolytidae)]. Redia 81: 183-197. [in Italian] Favaro A, Battisti A (1993). Observations on the elm bark beetle Scolytus pygmaeus (Fabricius) (Coleoptera, Scolytidae) as possible vector of the fungus Ophiostoma ulmi (Schwarz) Nannfeld. Redia 76: 459-466.

Francke-Grosmann H (1956a). Hautdrüsen als Träger der Pilzsymbiose bei Ambrosiakäfern [Mycangia as carriers of the fungus symbiosis with ambrosia beetles]. Zeitschrift für Morpholo- 
gie und Ökologie der Tiere 45: 275-308. [in German] - doi: 10.1007/BF00430256

Francke-Grosmann H (1956b). Grundlagen der Symbiose bei pilzzüchtenden Holzinsekten [Basics of symbiosis with fungus-growing wood insects]. Verhandlungen der Deutschen Zoologischen Gesellschaft Hamburg, Leipzig, Germany, pp. 112-118. [in German]

Francke-Grosmann H (1963a). Some new aspects in forest entomology. Annual Review of Entomology 8: 415-438. - doi: 10.1146/annurev.en. 08.010163 .002215

Francke-Grosmann H (1963b). Zur Übertragung der Pilzflora bei dem Borkenkäfer Ips acuminatus [Transfer of the fungal flora in the bark beetle Ips acuminatus]. Zeitschrift für Angewandte Entomologie 52: 355-361. [in German] - doi: 10.1111/j.1439-0418.1963.tb02 046.x

Francke-Grosmann H (1967). Ectosymbiosis in wood inhabiting insects. In: "Symbiosis. Associations of invertebrates, birds, ruminants and other biota (vol. 2)" (Henry SH ed). Academic Press, New York, USA, pp. 141-205.

Fransen JJ (1931). Enkele gegevens omtrent de verspreiding van de door Graphium ulmi Schwarz veroorzaakte iepenziekte door de iepenspintkevers, Eccoptogaster (Scolytus) scolytus F. en Eccoptogaster (Scolytus) multistriatus Marsh. in verband met de bestijding dezer ziekte [Comparing some data about spreading of Graphium ulmi Schwarz elm disease caused by the elm bark beetles, Eccoptogaster (Scolytus) Scolytus F. and Eccoptogaster (Scolytus) multistriatus Marsh. in connection with this disease]. Tijdschrift over Plantenziekten 37: 49-62. [in Dutch] Fransen JJ (1939). Iepenziekte, iepenspintkevers en beider bestrijding [Elm disease, elm bark beetles and their control]. Veenman and Zonen, Wageningen, The Netherland, pp. 118. [in Dutch]

Fransen JJ, Buisman C (1935). Infectieproeven op verschillende iepensoorten met behulp van de iepenspintkever [Experiments on different species of elm with the bark beetles]. Tijdschrift over Plantenziekten 41: 221-239. [in Dutch]

Ghelardini L, Santini A (2009). Avoidance by early flushing: a new perspective on Dutch elm disease research. iForest 2: 143-153. - doi: 10.383 2/ifor0508-002

Ghelardini L, Falusi M, Santini A (2006). Variation in timing of bud-burst of Ulmus minor clones from different geographical origins. Canadian Journal of Forest Research 36: 1982-1991. doi: 10.1139/x06-092

Ghelardini L, Santini A, Black-Samuelsson S, Myking T, Falusi M (2010). Bud dormancy release in elm (Ulmus spp.) clones - a case study of photoperiod and temperature responses. Tree Physiology 30: 264-274. - doi: 10.1093/treephys/ tpp 110

Gibbs JN (1974). Biology of Dutch elm disease Ceratocystsi ulmi. Forest Record 94: 1- 9.

Gibbs JN (1978). Intercontinental epidemiology of Dutch elm disease. Annual Review of Phytopathology 16: 287-307. - doi: 10.1146/annurev.py. 16.090178 .001443

Gibbs JN, Brasier CM (1973). Correlation be- tween cultural characters and pathogenicity in Ceratocystis ulmi from Britain, Europe and North America. Nature 241: 381-383. - doi: 10.1038/241381a0

Gibbs JN, Smith ME (1978). Antagonism during the saprophytic phase of the life cycles of two pathogens of woody host - Heterobasidium annosum and Ceratocystis ulmi. Annals of Applied Biology 89: 125-128. - doi: 10.1111/j.1744-73 48.1978.tb02586.x

Goidanich G (1936). La moria dell'olmo (Graphium ulmi) [The elm disease (Graphium ulmi)]. Reda, Roma, Italy, pp 124. [in Italian]

Goidanich A, Goidanich G (1937). Moria degli olmi e scolitidi [Elm decline and bark beetles]. Italia Agricola 71: 941-948. [in Italian]

Guries RP (2001). Elms: past, present, and future. In: Proceeding of the "National conference on wilt diseases of shade trees" (Ash CL ed). St. Paul (MN, USA) August 1999. APS Press, USA, pp. 29-36.

Herms DA, Mattson WJ (1992). The dilemma of plants - To grow or defend. Quarterly Review of Biology 67: 283-335. - doi: 10.1086/417659

Heybroek HM, Elgersma DM, Scheffer RJ (1982). Dutch elm disease: an ecological accident. Outlook on Agriculture 11: 1-9.

Jacobi WR, Koski RD, Harrington TC, Witcosky JJ (2007). Association of Ophiostoma novo-ulmi with Scolytus schevyrewi (Scolytidae) in Colorado. Plant Disease 91: 245-247. - doi: 10.1094/ PDIS-91-3-0245

Jacot AP (1934). Acarina as possible vector of the Dutch elm disease. Journal of Economic Entomology 27: 858-859.

Jacot AP (1936). Three possible mites vector of the Dutch elm disease. Entomological Society of America 29: 627-635.

Jeng RS, Alfenas AC, Hubbes M, Dumas MT (1983). Presence and accumulation of fungitoxic substances against Ceratocystis ulmi in Ulmus americana: possible relation to induced resistance. European Journal of Forest Pathology 13: 239-244. - doi: $10.1111 /$ j.1439-0329.1983.tb00 124.x

Kirisits T (2013). Dutch elm disease and other Ophiostoma diseases. In: "Infectious forest diseases" (Gonthier P, Nicolotti G eds). CABI, Wallingford, UK, pp. 256-282.

Kletecka Z (1996). The xylophagus beetles (Insecta, Coleoptera) community and its succession on Scotch elm (Ulmus glabra) branches. Biologia 51: 143-152. [online] URL: http://www.cabdirect.org/abstracts/19971100241.html

Lanier GN, Peacock JW (1981). Vectors of the pathogen. In: "Compendium of elm diseases" (Stipes RJ, Campana RJ eds). The American Phytopathological Society, St. Paul, MN, USA, pp. 14-16.

Lea T (1977). A comparison of the saprophitic and parasitic stages of Ceratocystis ulmi. Ph.D. Thesis, University of London, London, UK, pp. 77.

Lévieux J, Cassier P, Guillaumin D, Roques A (1991). Structures implicated in the transportation of pathogenic fungi by the European bark beetle, Ips sexdentatus Boerner: ultrastructure of a mycangium. Canadian Entomologist 123: 245254. - doi: 10.4039/Ent123245-2

Lorio PL (1986). Growth-differentiation balance provides a basis for understanding southern pine beetle-tree interactions. Forest Ecology and Management 14: 259-273. - doi: 10.1016/0378-112 7(86)90172-6

Lunderstadt J, Rohde M (1993). Biologie, Ausbreitungsstrategie und Bekampfungsmoglichkeiten der Ulmensplintkafer [Biology, dispersal strategy and possible fungus acquisition of the elm bark beetles]. Hessische Forstliche Versuchsanstalt, Hann Munden 16: 26-29. [in German]

Luchi N, Mancini V, Feducci M, Santini A, Capretti P (2012). Leptoglossus occidentalis and Diplodia pinea: a new insect-fungus association in Mediterranean forests. Forest Pathology 42: 246-251. - doi: 10.1111/j.1439-0329.2011.007 $50 . \mathrm{x}$

MacHardy WE, Beckman CH (1973). Water relations in American elm infected with Ceratocystis ulmi. Phytopathology 63: 98-103. - doi: 10.10 94/Phyto-63-98

Manojlovic B, Sivcev I (1995). The effect of elm bark thickness on Scolytus scolytus (F.) (Coleoptera: Scolytidae) growth in laboratory conditions. Zastita Bilja 46: 35-42. [online] URL: http://www.cabdirect.org/abstracts/19961100386 .html

Marcelis LFM (1996). Sink strength as a determinant of dry matter partitioning in the whole plant. Journal of Experimental Botany 47: 12811291. - doi: 10.1093/jxb/47.Special_Issue. 1281 Marchal E (1927). Rapport sur les résultats des recherches effectuées à la station de Phytopatologie de l'Etat à Gembloux sur la maladie de l'orme [Report on the research results of the Plant Pathology State Station of Gembloux's about elm disease]. Forestière de Belgique 35: 162-164. [in French]

Martín JA, Solla A, Esteban LG, de Palacios P, Gil L (2009). Bordered pit and ray morphology involvement in elm resistance to Ophiostoma novo-ulmi. Canadian Journal of Forest Research 39: 420-429. - doi: 10.1139/X08-183

Martin JA, Solla A, Ruiz-Villar M, Gil L (2013). Vessel length and conductivity of Ulmus branches: ontogenetic changes and relation to resistance to Dutch elm disease. Trees 27: 12391248. - doi: 10.1007/s00468-013-0872-2

McNabb HS, Heybroek HM, McDonald WL (1970). Anatomical factors in resistance to Dutch elm disease. Netherland Journal of Plant Pathology 76: 196-204. - doi: 10.1007/BF01974 331

Meyer HJ, Norris DM (1967). Vanillin and syringaldehyde as attractants for Scolytus multistriatus (Coleoptera: Scolytidae). Annals of the Entomological Society of America 60: 858-859. [online] URL: http://www.ingentaconnect.com/ content/esa/aesa/1967/00000060/00000004/art0 0024

Michalski J (1973). Revision of the paleartic species of the Scolytus Geoffroy (Coleoptera, Scolytidae). Panstwowe Wydawnictwo 
Naukowe, Warszava, Krakow, Poland, pp. 214. Mittempergher L (1989). Il declino dell'olmo: da latifoglia nobile a cespuglio [The elm decline: from tree to shrub]. Annali Accademia Italiana Scienze Forestali 38: 585-609.

Mittempergher L, Santini A (2004). The history of elm breeding. Investigación agraria: Sistemas y Recursos Forestales 13: 161-177. [online] URL: http://revistas.inia.es/index.php/fs/article/view/8 21

Moser JC, Konrad H, Blomquist SR, Kirisits T (2010). Do mites phoretic on elm bark beetles contribute to the transmission of Dutch elm disease? Naturwissenschaften 97: 219-227 - doi: 10.1007/s00114-009-0630-x

Neely D (1968). Twig inoculations on American elm with Ceratocystis ulmi. Phytopathology 58: 1566-1570.

Neely D (1970). Dutch elm disease symptom progression. Plant Disease Report 54: 127-129.

Newbanks D, Bosh A, Zimmermann MH (1983). Evidence for xylem dysfunction by embolization in Dutch elm disease. Phytopatology 73: 10601063. - doi: 10.1094/Phyto-73-1060

Ouellette GB, Rioux D (1992). Anatomical and physiological aspects of resistance to Dutch elm disease. In: "Defense mechanisms in woody plants against fungi" (Blanchette A, Biggs R eds). Springer-Verlag, Berlin, Germany, pp. 257 305 .

Ouellette GB, Rioux D, Simard M, Cherif M (2004a). Ultrastructural and cytochemical studies of host and pathogens in some fungal wilt diseases: retro- and introspection towards a better understanding. Investigación agraria: Sistemas y Recursos Forestales 13: 119-145. [online] URL: http://revistas.inia.es/index.php/fs/ article/view/819

Ouellette GB, Rioux D, Simard M, Chamberland H, Cherif M, Baayen RP (2004b). Ultrastructure of the alveolar network and its relation to coating on vessel walls in elms infected by Ophiostoma novo-ulmi and in other plants affected with similar wilt diseases. Investigación agraria: Sistemas y Recursos Forestales 13: 147-160. [online] URL: http://revistas.inia.es/index.php/fs/article/ view/820

Parker KG, Rankin WH, Collins DL (1941). Dutch Elm Disease fungus prevalent in bark beetle infested wood. Journal of Economic Entomology 34: 548-551.

Peacock JW, Lincoln AC, Simeone JB, Silverstein RM (1971). Attraction of Scolytus multistriatus (Coleoptera, Scolytidae) to a virgin female produced pheromone in the field. Annals of the Entomological Society of America 64: 1143-1149. [online] URL: http://www.ingentaconnect.com/ content/esa/aesa/1971/00000064/00000005/art0 0031

Pearce GT, Gore WE, Silverstein RM, Peacock JW, Cuthbert RA, Lanier GN, Simeone JB (1975). Chemical attractants for the smaller European elm bark beetle Scolytus multistriatus (Coleoptera: Scolytidae). Journal of Chemical Ecology 1: 115-124. - doi: 10.1007/BF00987724 Pecori F, Bottacci A, Migliorini D, Santini A
(2013). Monitoring Wych elm population in southern Apennines. In: Proceedings of the " 3 rd International Elm Conference. The elm after 10 years of Dutch elm disease" (Manzo R ed). Florence (Italy) 9-11 October 2013. IPP-CNR, Florence, Italy, pp. 40. [online] URL: http:// elm2013.ipp.cnr.it/downloads/book_of_abstracts.pdf

Pfeffer A (1995). Zentral- und westpaläarktische Borken- und Kernkäfer (Coleoptera: Scolytidae, Platypodidae) [Central and Western Palearctic Bark and Ambrosia beetles (Coleoptera: Scolytidae, Platypodidae)]. Pro Entomologica, Naturhistorisches Museum Basel, Switzerland, pp. 310.

Pomerleau R (1965). The period of susceptibility of Ulmus americana to Ceratocystis ulmi under conditions prevailing in Quebec. Canadian Journal of Botany 43: 787-792. - doi: 10.1139/b65089

Pomerleau R (1968). Progression et localisation de l'infection par le Ceratocystis ulmi dans l'orme d'Amérique [Progression and localization of the infection by Ceratocystis ulmi in the American elm]. Phytopathologische Zeitschrift 63: 301-327. [in French] - doi: 10.1111/j.14390434.1968.tb02396.x

Pope SA (1943). Some studies on the Dutch elm disease and the causal organism. Doctoral Thesis, Cornell University, Ithaca, NY, USA, pp. 66. Rioux D, Ouellette GB (1991a). Barrier zone formation in host and nonhost trees inoculated with Ophiostoma ulmi. I. Anatomy and histochemistry. Canadian Journal of Botany 69: 20552073. - doi: 10.1139/b91-258

Rioux D, Ouellette GB (1991b). Barrier zone formation in host and nonhost trees inoculated with Ophiostoma ulmi. II. Ultrastructure. Canadian Journal of Botany 69: 2074-2083. - doi: 10.113 9/b91-259

Rioux D, Nicole M, Simard M, Ouellette GB (1998). Immunocytochemical evidence that secretion of pectin occurs during gel (gum) and tylosis formation in trees. Phytopathology 88: 494505. - doi: 10.1094/PHYTO.1998.88.6.494

Rohring E (1996). Elms in Europe: ecology and Dutch elm disease. Forstarchiv 67: 179-198.

Rudinsky JA (1962). Ecology of Scolytidae. Annual Review of Entomology 7: 327-348 - doi: 10.1146/annurev.en.07.010162.001551

Sacchetti P, Tiberi R, Mittempergher L (1990). Preferenza di Scolytus multistriatus (Marsham) durante la fase di maturazione delle gonadi nei confronti di due specie di olmo [Preference of Scolytus multistriatus (Marsham) during the maturation feeding for two species of elm]. Redia, pp. 347-354. [in Italian]

Santini A, Fagnani A, Ferrini F, Ghelardini L, Mittempergher L (2005a). Variation among Italian and French elm clones in their response to Ophiostoma novo-ulmi inoculation. Forest Pathology 35: 183-193. - doi: 10.1111/j.1439-032 9.2005.00401.x

Santini A, Ghelardini L, Falusi M, Bohnens J, Buron M, Collin E, Solla A, Van den Broeck, A (2004). Vegetative bud-burst variability of Euro- pean elms. In: Proceedings of the $2^{\text {nd }}$ International Elm Conference "New approaches to elm conservation". Valsaìn (Spain) 20-23 May 2003. Investigatión Agraria: Sistemas y Recursos Forestales 13: 37-45. [online] URL: http://revistas. inia.es/index.php/fs/article/view/811

Santini A, Montaghi A, Vendramin GG, Capretti P (2005b). Analysis of the Italian Dutch elm disease population. Journal of Phytopathology 153: 73-79. - doi: 10.1111/j.1439-0434.2004.00931.x Schwarz MB (1922). The twig vascular disease of the elm. Das Zweig-sterben der Ulmen, Trauerweiden und Pfirsichbaume [The twig vascular disease of the elm, willows and peach trees] Medelingen uit het Phytopathologisch laboratorium Willie Commelin Scholten 5: 1-73. [in German]

Sengonca C, Leisse N (1984). Bedeutung der Borkenkafer (Col., Scolytidae) bei der Verbreitung des Erregers der Hollandischen Ulmenkrankheit im Raum Euskirchen [Importance of bark beetles (Col., Scolytidae) in the dissemination the causal agent of the Dutch-Indian elm disease in the area of Euskirchen]. Journal of Applied Entomology 98: 413-423. [in German]

Shigo AL (1982). Dutch elm disease: a CODIT perspective. In: Proceedings of the "Dutch elm disease symposium and workshop" (Kondo ES, Hiratsuka Y, Denyer WBG eds). Winnipeg (Canada) 5-9 October 1981, pp. 151-168.

Shigo AL, Tippet JT (1981). Compartmentalization of America elm tissues infected with Ceratocystis ulmi. Plant Disease 65: 715-718. - doi: 10.1094/PD-65-715

Sinclair WA, Campana RJ (1978). Dutch elm disease: perspectives after 60 years. Plant Pathology 1: 5-52. [online] URL: http://www.cabdirect.org/ abstracts/19800671247.html

Sinclair WA, Zahand JP, Melching JB (1975). Anatomical markers for resistance of Ulmus americana to Ceratocystis ulmi. Phytopathology 65: 349-352. - doi: 10.1094/Phyto-65-349

Six DL (2012). Ecological and evolutionary determinants of bark beetle-fungus symbioses. Insects 3: 339-366. - doi: 10.3390/insects3010339

Smalley EB, Guries RP (2000). Asian elms: source of disease and pest resistance. In: "The Elms: Breeding, Conservation, and Disease Management" (Dunn CP ed). Kluver Academic Publishers, Boston, USA, pp. 215-230.

Smalley EB, Kais AG (1966). Seasonal variation in the resistance of various elm species to Dutch elm disease. In: "Breeding Pest-Resistant Trees" (Gerhold HD, Schreiner EJ, Mc Dermott RE, Winieski JA eds). Pergamon Press, Elmsford, NY, USA, pp. 279-292.

Smalley EG (1963). Seasonal fluctuations in susceptibility of young elm seedlings to Dutch elm disease. Phytopathology 53: 846-853.

Smucker SJ (1935). Air currents as possible carriers of Ceratostomella ulmi. Phytopathology 25: 442-443.

Solla A, Gil L (2002a). Influence of water stress on Dutch elm disease symptoms in Ulmus minor Miller. Canadian Journal of Botany 80: 810-817. - doi: 10.1139/b02-067 
Solla A, Gil L (2002b). Xylem vessel diameter as a factor in resistance of Ulmus minor to Ophiostoma novo-ulmi. Forest Pathology 32: 123-134. - doi: 10.1046/j.1439-0329.2002.0027 4.x

Solla A, Martin JA, Corral P, Gil L (2005a). Seasonal changes in wood formation of Ulmus pumila and $U$. minor and its relation with Dutch elm disease. New Phytologist 166: 1025-1034. doi: 10.1111/j.1469-8137.2005.01384.x

Solla A, Martin JA, Ouellette G, Gil L (2005b). Influence of plant age on symptom development in Ulmus minor following inoculation by Ophiostoma novo-ulmi. Plant Disease 89: 1035-1040. doi: 10.1094/PD-89-1035

Spierenburg T (1921). Een onbekende ziekte in de iepen [An unknown disease in elm]. Tijdschrift over Plantenziekten 27: 53-61.

Stark VN (1952). Fauna SSSR, vol. 31 (Scolytidae). Koroedy, Akad N SSSR, Moskva, Leningrad, Russia, pp 462.

Sticklen MB, Bolyard MG, Hajela RK, Duchesne LC (1991). Molecular and cellular aspects of Dutch elm disease. Phytoprotection 72: 1-13. doi: 10.7202/705997ar

Stipes RJ, Campana R (1981). Compendium of elm diseases. American Phytopathological Society, St Paul, MN, USA, pp 66. [online] URL: http://www.cabdirect.org/abstracts/19811376781 .html

Sutherland ML, Brasier CM (1997). A comparison of thirteen d-factors as potential biological control of agents of Ophiostoma novo-ulmi. Plant Pathology 46: 680-693. - doi: 10.1046/j.13 65-3059.1997.d01-62.x

Svihra P, Clark JK (1980). The courtship of the elm bark beetles. California Agriculture 4: 7-9.
Takai S, Kondo ES (1979). Seasonal development of Dutch elm disease on white elms in Central Ontario, Canada. I. Following wound inoculation. Canadian Journal of Botany 57: 341-352. doi: 10.1139/b79-046

Tchernoff V (1965). Methods for screening and for the rapid selection of elms for resistance to Dutch elm disease. Acta Botanica Neerlandica 14: 409-452. - doi: 10.1111/j.1438-8677.1965. tb00204.x

Tyree MT, Zimmermann MH (2002). Xylem structure and the ascent of sap. Springer Verlag, NY, USA, pp. 285

Ware G (1995). Little-known elms from China: landscape tree possibilities. Journal of Arboriculture 21: 284-288.

Webber JF (1990). Relative effectiveness of Scolytus scolytus, S. multistiatus and S. kirschi as vectors of Dutch elm disease. European Journal of Forest Pathology 20: 184-192. - doi: 10.1111/j.1439-0329.1990.tb01129.x

Webber JF (2000). Insect vector behaviour and the evolution of Dutch elm disease. In: "The elms: breeding, conservation and disease management" (Dunn CP ed). Kluwer Academic Publishers, Boston, USA, pp. 47-60.

Webber JF, Brasier CM (1984). The transmission of Dutch elm disease: a study of the process involved. In: "Invertebrate-Microbial Interactions" (Anderson JM, Rayner ADM, Walton D eds). Cambridge University Press, Cambridge, UK, pp. 271-306.

Webber JF, Gibbs JN (1989). Insect dissemination of fungal pathogens of trees. In: Proceedings of the $14^{\text {th }}$ Symposium of the Royal Entomological Society of London / British Mycological Society
"Insect-Fungus Interactions" (Wilding N, Collins NM, Hammond PM, Webber JF eds). Academic Press, London, UK, pp. 541-546.

Webber JF, Kirby JN (1983). Host feeding preference of Scolytus scolytus. Forest Commission Bulletin 60: 47-49.

Westerdijk J, Buisman C (1929). De iepenziekte. Rapport over het ondeszoek verricht op verzoek van de Nederlandsche Heidemaatschappij [The elm disease. Report on the probe looking out at the request by the Dutch Society Heath]. Arnhem, The Netherlands, pp. 122. [in Dutch]

Wood DL (1982). The role of pheromones, kairomones, and allomones in the host selectioin and colonization behaviour of bark beetles. Annual Review of Entomology 27: 411-446. - doi: 10.11 46/annurev.en.27.010182.002211

Wood SL, Bright DE (1992). A catalogue of Scolytidae and Platypodidae (Coleoptera), part 2: taxonomic index. Great Basin Naturalist Memoirs 13: 1-1553.

Zalapa JE, Brunet J, Guries RP (2009). Patterns of hybridization and introgression between invasive Ulmus pumila (Ulmaceae) and native $U$. rubra. American Journal of Botany 96: 1116-1128. doi: 10.3732/ajb.0800334

Zanta F, Battisti A (1990). Notes on the distribution and biology of the elm bark beetles in northeastern Italy (Coleoptera Scolytidae). Gortania Atti Museo Friulano di Storia Naturale, Udine 11: 189-205.

Zimmermann MH, McDonough J (1978). Dysfunction in the flow of food. In: "Plant disease - an advanced treatise, vol 3: How plants suffer from disease" (Horsfall JG, Cowling ED eds). Academic Press, New York, USA, pp. 117-140. 